\title{
FREE-HAND PLACEMENT OF C7 PEDICLE SCREWS: A CADAVERIC STUDY
}

\author{
INSERÇÃO DE PARAFUSOS PEDICULARES EM C7 COM A TÉCNICA À MÃO LIVRE: \\ UM ESTUDO EM CADÁVERES
}

INSERCIÓN DE TORNILLOS PEDICULARES EN C7 A MANOS LIBRES: UN ESTUDIO EN CADÁVERES

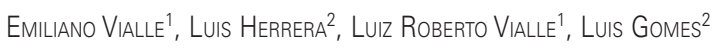

\begin{abstract}
Objective: To evaluate the accuracy of free-hand pedicle screws placement at the seventh cervical vertebra. Methods: The authors have exposed the cervicothoracic junction of 9 adult cadavers ( 7 male and 2 female) preserved in formalin from the Faculty of Medicine of the Universidad Andina Néstor Cáceres Velásquez, city of Juliaca, Puno - Peru, locating the C7 vertebra based on anatomical parameters. According to previous publications, the entry point for the C7 pedicle was determined as 3-4mm lateral and 5-6mm superior to the center of the lateral mass, and the pedicle was drilled manually and instrumented with $3.5 \mathrm{~mm}$ screws. After the screws placement, the C7 vertebrae were removed for radiographic analysis. Results: The authors were able to adequately locate the C7 entry point in 12 pedicles (66.6\% accuracy), finding a great variability both laterally $(2-5 \mathrm{~mm})$ and cranially (3-10mm). The angulation in the coronal plane was correct in 13 pedicles (72.3\%), despite the incorrect location of the entry point. Angle values in the coronal plane ranged from 38 to 62 degrees. In the sagittal plane angulation, 2 screws were placed in the C6-C7 disc. The midtransversal diameter of the 18 pedicles ranged from 4 to $7 \mathrm{~mm}$. Conclusions: The location of the entry point for placement of $\mathrm{C} 7 \mathrm{pedicle}$ screws with pure free-hand technique is very variable due to anatomical differences and the authors recommend some type of guidance for increased safety and accuracy.
\end{abstract}

Keywords: Pedicle screws; Cervical vertebrae; Orthopedic procedures.

\section{RESUMO}

Objetivo: Avaliar a acurácia do posicionamento de parafusos pediculares na sétima vértebra cervical pela técnica à mão livre. Métodos: Os autores dissecaram a junção cervicotorácica de nove cadáveres de adultos da Faculdade de Medicina da Universidad Andina Néstor Cáceres Velásquez, da cidade de Juliaca, Puno, Peru, localizando a sétima vértebra cervical com base em parâmetros anatômicos. De acordo com publicações prévias, o ponto de entrada do pedículo de C7 foi determinado como 3-4 mm lateral e 5-6 mm superior ao centro da massa lateral; o pedículo foi perfurado manualmente e instrumentado com parafusos de 3,5 mm. As vértebras foram removidas para avaliação radiográfica. Resultados: Os autores foram capazes de localizar precisamente o ponto de entrada para C7 em 12 pedículos (acurácia de 66,6\%), encontrando grande variabilidade tanto no sentido lateral (2 a $5 \mathrm{~mm}$ ) quanto no craniano (3 a $10 \mathrm{~mm}$ ). A angulação no plano coronal foi correta em 13 pedículos (72,3\%), apesar da localização incorreta do ponto de entrada. Os valores dos ângulos no plano coronal variaram de 38 a 62 graus. Na angulação do plano sagital, foram colocados dois parafusos no disco de C6-C7. O diâmetro mesotransversal dos 18 pedículos variou de 4 a $7 \mathrm{~mm}$. Conclusão: A localização do ponto de entrada dos parafusos pediculares em C7 com a técnica à mão livre é muito variável em decorrência das diferenças anatômicas e os autores recomendam algum tipo de orientação auxiliar para aumentar a segurança e a acurácia.

Descritores: Parafusos pediculares; Vértebras cervicais; Procedimentos ortopédicos.

\section{RESUMEN}

Objetivo: Evaluar la exactitud de la colocación de tornillos pediculares enla séptima vértebra cervical con la técnica de manos libres. Métodos: Los autores disecaron la unión cervicotorácica de 9 cadáveres adultos (7 hombres y 2 mujeres) conservados en formol de la Facultad de Medicina de la Universidad Andina Néstor Cáceres Velásquez de la ciudad de Juliaca, Puno - Perú, localizando la vértebra C7 con base en los parámetros anatómicos. De acuerdo con publicaciones anteriores, el punto de entrada para la colocación de tornillos pediculares en la vértebra C7 se determinó como 3-4 mm lateral y 5-6 mm superior al punto central de la masa lateral, y se procedió al drilado del pedículo manualmentey a la colocación de tornillos pediculares de 3,5 mm. Luego de la colocación de los tornillos las vértebras C7 fueron retiradas del cadáver para el análisis radiográfico. Resultados: Los autores fueron capaces de localizar adecuadamente el punto de entrada de C7 en 12 pedículos (66,6\% de exactitud), se encontrando gran variabilidad en lo que se refiere tanto en la distancia hacia lateral (2-5 mm) como hacia craneal (3-10 mm). La angulación en el plano coronal estuvo correcta en 13 pedículos (72,3\%), a pesar de la ubicación incorrecta del punto de entrada. Los valores de los ángulos en el plano coronal variaron de 38 a 62 grados. En la angulación del plano sagital, dos tornillos se colocaron en el disco C6-C7. El diámetro medio transversal de los 18 pedículos osciló entre 4 a 7 mm. Conclusiones: La localización del punto de entrada para la colocación de tornillos pediculares C7 con la técnica de manos libres es muy variable debido a las diferencias anatómicas. Los autores recomiendan utilizar algún tipo de guía para incrementar la precisión y seguridad.

Descriptores: Tornillos pediculares; Vértebras cervicales; Procedimientos ortopédicos.

1. Pontifícia Universidade Católica do Paraná, Hospital Universitário Cajuru, Orthopedics and Traumatology Service, Spine Surgery Group, Curitiba, PR, Brazil.

2. Neurosurgery Unit of the American Clinic Juliaca and Hospital ESSALUD, Department of Surgery, Puno, Peru.

Work performed at Faculdade de Medicina da Universidade Andina Néstor Cáceres Velásquez, Puno, Peru.

Correspondência: Rua Brigadeiro Franco, 979. Curitiba, PR, Brasil.80430-210. evialle@ hotmail.com 


\section{INTRODUCTION}

The cervicothoracic junction is a complex region, in which dramatic anatomic and biomechanical changes take place. Within the field of anatomy, changes in vertebral diameter, mineral density and fixation points from the mid cervical to the upper thoracic spine are challenges that need to be overcome in order to accommodate biomechanical adaptations from the lordotic and mobile portion to a rigid and kyphotic upper thoracic region.

In the cervical spine, lateral mass screws have proven to be safe and biomechanically stable fixation points in most cases, and thoracic pedicle screws have become a standard fixation option for the T1 and caudal vertebrae. On the other hand, the C7 vertebra remains a challenge for those operating on the cervicothoracic junction. The lateral masses of C7 may have decreased depth in comparison to upper lateral masses, with decreased pullout strength, which has led surgeons to seek other fixation options, such as the lamina and pedicle screws. ${ }^{1,2}$

The biomechanical stability offered by pedicle screws for treating traumatic, degenerative, inflammatory, and neoplastic conditions of the spine is well known. ${ }^{3-5}$ However, cervical pedicle screw insertion is technically demanding because of the anatomical variations in cervical pedicle size, the lack of anatomical landmarks, and the transverse angle of cervical pedicles. ${ }^{3,6-8}$

Previous studies have shown that the accuracy of the placement of pedicle screws in the cervical spine ranges from 16.8 to $97 \%$, depending on surgeon's experience. ${ }^{9-14}$ The spine surgeon must have a good understanding the morphology of the C7 vertebra in order to identify the proper entry point and the angulation needed for placement of pedicle screws without causing neural or vascular damage. ${ }^{15,16}$

Various surgical techniques have been developed, including the use of laminoforaminotomy, ${ }^{12,14}$ the "funnel technique", ${ }^{10}$ cannulated screws ${ }^{14}$ and computer-assisted navigation system. ${ }^{11,17}$ Navigation systems have significantly improved screw accuracy, but its application has been limited by its high cost and lengthy registration procedure. Intraoperative imaging with the $\mathrm{C}$-arm is another possibility, but visualization is difficult, if not impossible, due to patient's anatomy and surgical positioning, besides exposing both surgeon and patient to significant amounts of radiation.

Lee et al. ${ }^{18}$ based on the $3 \mathrm{D}$ reconstruction of multidetector computer tomography (MD-CT) images and surgery simulation program, determined the optimal entry points for cervical pedicle screws in Asian population.

Recently Lee et al. ${ }^{19}$ performed cervical pedicle screw placement using the Key Slot technique with 90\% accuracy and correct positioning with no clinical complications, but always with intra-operative radiological assistance.

There are no pure freehand C7 screw placement reports without the assistance of radiological devices or osseous drilling techniques. The purpose of this study is to evaluate the accuracy of free hand pedicle screw insertion at $\mathrm{C} 7$ in cadaveric specimens.

\section{METHODS}

The authors have performed posterior midline cervicothoracic exposure on nine human cadavers preserved with formalin, provided by the Faculty of Medicine of the Néstor Cáceres Velásquez Andean University. The C7 vertebrae was completely exposed bilaterally, down to its transverse process, and the entry point was determined on the surface of the lateral mass, based on the entry point described by Dong-Ho Lee. ${ }^{18}$ This entry point is located $2 \mathrm{~mm}$ lateral and superior to the center of the lateral mass. In the first anatomic specimen the authors found this entry point to be inaccurate, because the screws were located too caudal to the pedicle. New measurements led the authors to redefine the entry point $3-4 \mathrm{~mm}$ lateral to the center of the lateral mass and 5-6mm superior to this point. (Figure 1) Regarding the screw angulation we relied on the work of Sang-Hun Lee ${ }^{19}$ in which the midpoint of the articular mass is the projection of a triangle that points to the base of the pedicle. (Figure 2)
The $3.5 \mathrm{~mm}$ screws were inserted (Depuy-Synthes), according to these parameters, in the 16 remaining pedicles, without any exposure of the pedicles or drilling of the lateral mass. No radiological assistance was used. After screw placement, C7 was completely dissected and removed for analysis. Distances and pedicle width were made using an electronic caliper, and angulation was calculated based on the digital radiograph of nine vertebrae. The mean (m) and standard deviation (sd) of all these measurements were calculated. Because this was a study on cadavers, it did not need to be submitted to the Institutional Review Board

\section{RESULTS}

An adequate entry point was found in 12 of the 18 pedicles (66.6\% accuracy, Figure 3$)$. The authors found great variability in terms of the point of entry of the pedicle in the $\mathrm{C} 7$ lateral mass in relation to its center point, with values ranging from $2 \mathrm{~mm}$ to $5 \mathrm{~mm}$ laterally (mean of 3.3 for both sides - standard deviation 2.7 right and 2.0 left) and $3 \mathrm{~mm}$ to $10 \mathrm{~mm}$ superior to it (mean $5.8 \pm 6.9$ right and mean $5.6 \pm 6.1$ left). (Table 1) The angulation in the coronal plane was correct in 13 pedicles (72.2\%, figure 3 ), where the screws were parallel to the pedicles, despite some of them having breached any of the walls. The pedicle angle values in the coronal plane were also highly variable, ranging from 38 to 62 degrees (m $49.67^{\circ}$-sd $6.64^{\circ}$ on the right side and $\mathrm{m} 47.89^{\circ}$-sd $6.35^{\circ}$ on the left side), but manual palpation of the trajectory probably compensated for this variation. (Table 2) In the sagittal plane angulation, 2 screws were misplaced cranially, touching the C6-C7 disc. The transversal diameter of the $\mathrm{C} 7$ pedicles ranged from 4 to $7 \mathrm{~mm}$ ( $\mathrm{m} 5.83$-sd 2.83mm in the right pedicle and $\mathrm{m}$ 5.92-sd $2.96 \mathrm{~mm}$ in the left pedicle). (Table 3 )

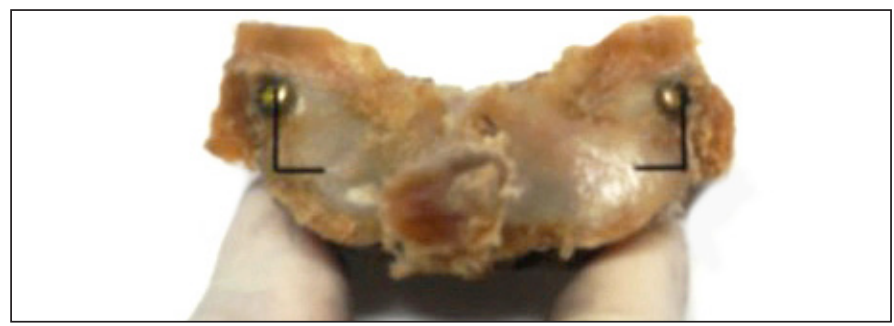

Figure 1. The distance of the entry point at $\mathrm{C} 7$ pedicle screws from the midpoint (MP) of the lateral mass of the specimen 5 of the $\mathrm{C} 7$.

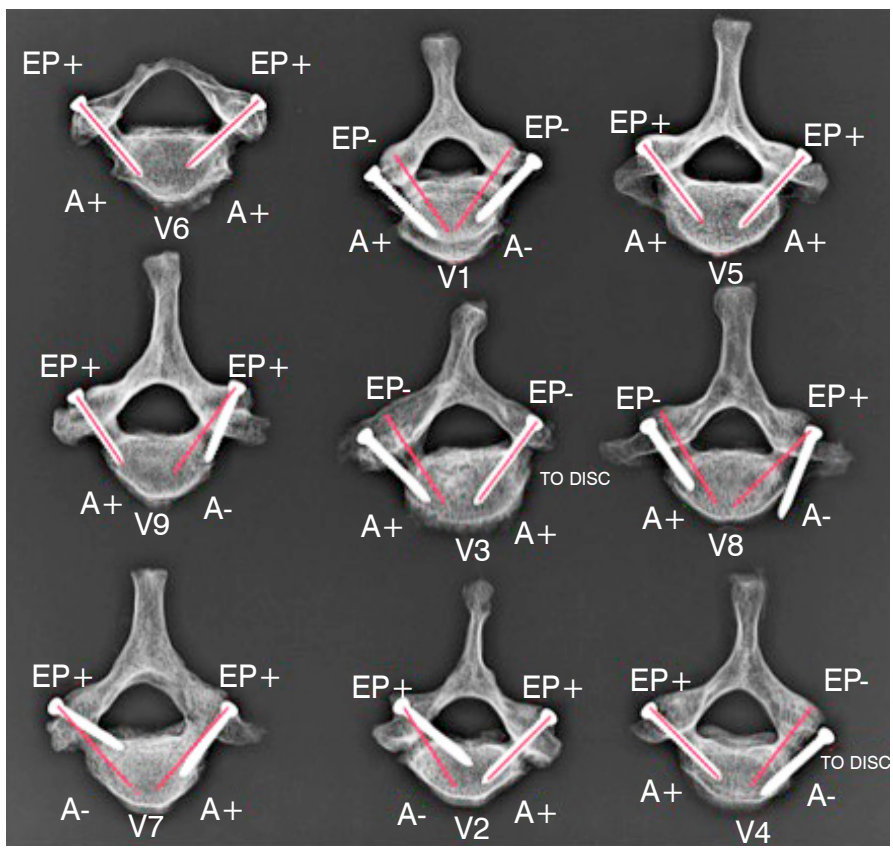

Figure 2. Digital radiograph of the 9 specimens. EP+ (correct entry point), EP- (incorrect entry point), $\mathrm{A}+$ : correct angulation, $\mathrm{A}$-: incorrect angulation. 


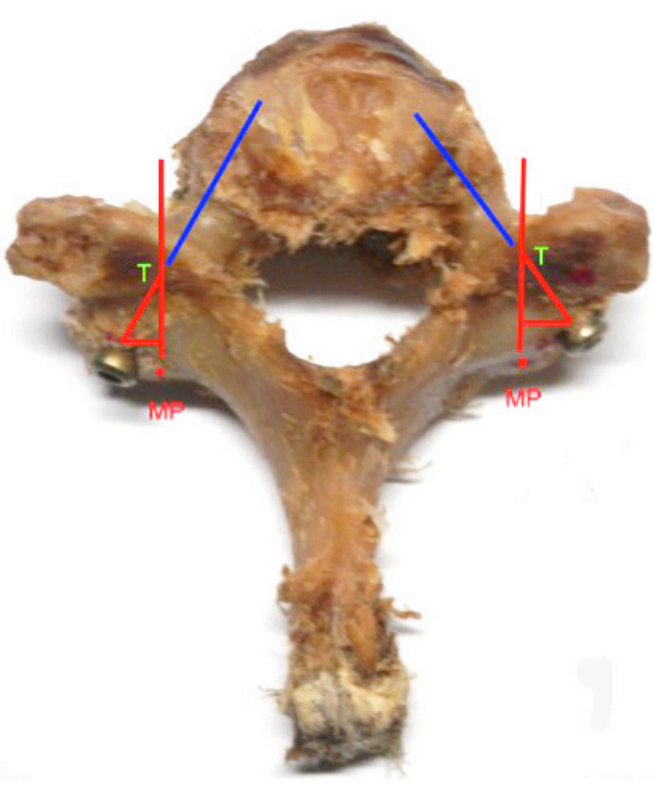

Figure 3. The midpoint (MP) of the articular mass is the projection of a triangle (T) that points to the base of the pedicle.

Table 1. Mean values for the ideal entry point for each specimen.

\begin{tabular}{c|c|c|c|c|c}
\hline Distance from center & To lateral & To lateral & To superior & To superior & sex \\
\hline of articular mass & (right) & (left) & (right) & (left) & male \\
\hline Vertebra 01 & $4 \mathrm{~mm}$ & $3 \mathrm{~mm}$ & $10 \mathrm{~mm}$ & $10 \mathrm{~mm}$ & male \\
\hline Vertebra 02 & $3 \mathrm{~mm}$ & $3 \mathrm{~mm}$ & $4.5 \mathrm{~mm}$ & $4.5 \mathrm{~mm}$ & male \\
\hline Vertebra 03 & $2 \mathrm{~mm}$ & $3 \mathrm{~mm}$ & $3 \mathrm{~mm}$ & $3 \mathrm{~mm}$ & Female \\
\hline Vertebra 04 & $2 \mathrm{~mm}$ & $3 \mathrm{~mm}$ & $3.5 \mathrm{~mm}$ & $4 \mathrm{~mm}$ & male \\
\hline Vertebra 05 & $4 \mathrm{~mm}$ & $3 \mathrm{~mm}$ & $8 \mathrm{~mm}$ & $8 \mathrm{~mm}$ & Female \\
\hline Vertebra 06 & $3.5 \mathrm{~mm}$ & $4 \mathrm{~mm}$ & $5 \mathrm{~mm}$ & $5 \mathrm{~mm}$ & male \\
\hline Vertebra 07 & $4 \mathrm{~mm}$ & $5 \mathrm{~mm}$ & $5 \mathrm{~mm}$ & $5 \mathrm{~mm}$ & male \\
\hline Vertebra 08 & $5 \mathrm{~mm}$ & $3.5 \mathrm{~mm}$ & $9 \mathrm{~mm}$ & $7 \mathrm{~mm}$ & male \\
\hline Vertebra 09 & $2.5 \mathrm{~mm}$ & $2.5 \mathrm{~mm}$ & $4.5 \mathrm{~mm}$ & $4.5 \mathrm{~mm}$ & \\
\hline Mean & $3.3 \mathrm{~mm}$ & $3.3 \mathrm{~mm}$ & $5.8 \mathrm{~mm}$ & $5.6 \mathrm{~mm}$ & \\
\hline SD & $2.7 \mathrm{~mm}$ & $2.0 \mathrm{~mm}$ & $6.9 \mathrm{~mm}$ & $6.1 \mathrm{~mm}$ & \\
\hline
\end{tabular}

Table 2. $\mathrm{C} 7$ pedicle angulation.

\begin{tabular}{c|c|c}
\hline Vertebra & Right pedicle angle & Left pedicle angle \\
\hline 1 & $55^{\circ}$ & $50^{\circ}$ \\
\hline 2 & $62^{\circ}$ & $38^{\circ}$ \\
\hline 3 & $47^{\circ}$ & $55^{\circ}$ \\
\hline 4 & $45^{\circ}$ & $55^{\circ}$ \\
\hline 5 & $55^{\circ}$ & $50^{\circ}$ \\
\hline 6 & $38^{\circ}$ & $38^{\circ}$ \\
\hline 7 & $45^{\circ}$ & $45^{\circ}$ \\
\hline 8 & $50^{\circ}$ & $50^{\circ}$ \\
\hline 9 & $50^{\circ}$ & $50^{\circ}$ \\
\hline Mean & $49.67^{\circ}$ & $47.89^{\circ}$ \\
\hline SD & $6.64^{\circ}$ & $6.35^{\circ}$ \\
\hline
\end{tabular}

Legend: $\mathrm{SD}=$ standard deviation
Table 3. Pedicle width measurements.

\begin{tabular}{c|c|c}
\hline Vertebra & Right pedicle widht & Left pedicle width \\
\hline 1 & $6.5 \mathrm{~mm}$ & $6.5 \mathrm{~mm}$ \\
\hline 2 & $5 \mathrm{~mm}$ & $5 \mathrm{~mm}$ \\
\hline 3 & $7 \mathrm{~mm}$ & $5.8 \mathrm{~mm}$ \\
\hline 4 & $5 \mathrm{~mm}$ & $5 \mathrm{~mm}$ \\
\hline 5 & $6 \mathrm{~mm}$ & $7 \mathrm{~mm}$ \\
\hline 6 & $4 \mathrm{~mm}$ & $4 \mathrm{~mm}$ \\
\hline 7 & $7 \mathrm{~mm}$ & $7 \mathrm{~mm}$ \\
\hline 8 & $6 \mathrm{~mm}$ & $6.5 \mathrm{~mm}$ \\
\hline 9 & $6 \mathrm{~mm}$ & $6.5 \mathrm{~mm}$ \\
\hline Mean & $5.83 \mathrm{~mm}$ & $5.92 \mathrm{~mm}$ \\
\hline$S D$ & $2.83 \mathrm{~mm}$ & $2.96 \mathrm{~mm}$ \\
\hline
\end{tabular}

Legend: $\mathrm{SD}=$ standard deviation

\section{DISCUSSION}

Anatomical studies have reported unsuccessful cervical screw placement in up to $87.5 \% .{ }^{14}$ Zheng et al. ${ }^{9}$ have reported $100 \%$ accuracy in the placement of pedicle screws at $\mathrm{C} 7$, based on the entry point and angulation recommended by Rao and with the aid of fluroscopy. Zheng's study showed that the entry point at $\mathrm{C} 7$ is one half of the width of the lateral mass, and $2 \mathrm{~mm}$ from the inferior margin of the superior articular facet, with an angulation of $33^{\circ} \pm 4^{\circ}$. Previous studies have tried to locate the entry point in the cervical pedicle including $\mathrm{C} 7$, all using techniques that remove parts of the lateral mass, lamina, etc. ${ }^{3}$

Lee et al., ${ }^{19}$ in their study using three dimensional CT images of the cervical spine determined the entry point for $\mathrm{C} 7$ in the Korean population, as $2 \mathrm{~mm}$ superior and lateral to the center of the lateral mass, with a pedicle angulation of $28^{\circ}$.

Other authors have reported that computer-assisted navigation systems have lower pedicle perforation rates than freehand techniques. ${ }^{14,20,21}$ Three-dimensional fluoroscopy is superior to conventional CT-based image guidance because anatomical registration is not required, and real-time updates of the spine position can be obtained intraoperatively. Ito et al. ${ }^{22}$ and Ishikawa et al. ${ }^{21}$ report pedicle perforation rates of $2.8 \%$ and $18.7 \%$ respectively, when a three-dimensional fluoroscopy-based navigation system was used. The computer-assisted navigation system and the three dimensional fluoroscopy are very expensive, and not all centers in the world can afford them.

There are two studies using only fluoroscopy in the placement of C7 pedicles screws. Yukawa et al. ${ }^{23}$ reported successful results, with $13 \%$ screw malposition, including $9.2 \%$ screw exposure and $3.9 \%$ pedicle perforation. Desai et al. ${ }^{24}$ using c-arm a-p image, inserted 56 C7 pedicle screws, with only one screw breaching the lateral wall. They recommended a screw angulation of 25-30 degrees.

In our work, we have tested a pure free hand technique for placement of screws at C7 without the help of fluoroscopy or any osseous opening technique to palpate the pedicles, and we have found that the entry point at $\mathrm{C} 7$ is very variable. Taking the center of the lateral mass as a mark, we have determined with accuracy was $66.6 \%$ (12 out of 18 pedicles instrumented) that the pedicle entry point varies from 2 to $5 \mathrm{~mm}$ laterally and from 3 to $10 \mathrm{~mm}$ cranially. We were not able to reach the same level accuracy as the fluoro guided studies of Yukuwa et al. ${ }^{23}$ and Desai et al., ${ }^{24}$ confirming the superiority of fluoroscopy, if anatomy and positioning allows for adequate viewing of the $\mathrm{C} 7$ pedicle. The angulation in the coronal plane was correct in 13 pedicles (72.2\%), and despite the incorrect location of the entry point, the angulation was parallel to the pedicle. Angle values of the $\mathrm{C} 7$ pedicles in the coronal plane in our cadaveric study were very variable, from 38 to 62 degrees, and these values are very different from those of many other authors. ${ }^{3,6,7,9,12,18}$ In Lee's study, ${ }^{19}$ the midpoint of the articular mass is the projection of a triangle that points to the base of the cervical pedicle, providing is a very useful tool in a pure free hand C7 pedicle screw placement. We also believe that manual palpation of the least resistant pathway helps improve accuracy in the coronal plane evaluation. 


\section{CONCLUSION}

This work did not use any pre-operative radiological imaging or intraoperative radiation, and was performed on cadavers, which differs from live surgery. Also, we did not perform any reduction procedure of the lateral mass of $\mathrm{C} 7$, obtaining a correct location of the entry point in $66.6 \%$ (12 out of 18 pedicles) and a correct angulation in the axial plane of the pedicle screws of $72.2 \%$ (13 out of 18 pedicles).

In short, the location of the entry point for placement of $\mathrm{C} 7 \mathrm{pe}$ dicle screws in a pure free hand technique is variable due to anatomical differences, and puts the neurovascular structures at risk.
The authors recommend image guidance or medial wall palpation for increased safety and accuracy of C7 pedicle screws.

\section{ACKNOWLEDGMENTS}

The authors wish to thank the Néstor Cáceres Velásquez Andean University of Juliaca and the American Clinic of Juliaca for supporting this study.

All authors declare no potential conflict of interest concerning this article.

\section{REFERENCES}

1. Jang WY, Kim IS, Lee HJ, Sung JH, Lee SW, Hong JT. A computed tomography-based anatomic comparison of three different types of c7 posterior fixation techniques: pedicle, intralaminar, and lateral mass screws. J Korean Neurosurg Soc. 2011:50(3):166-72.

2. Xu R, McGirt MJ, Sutter EG, Sciubba DM, Wolinsky JP. Witham TF, Gokaslan ZL, et al. Biomechanical comparison between C-7 lateral mass and pedicle screws in subaxial cervical constructs. Presented at the 2009 Joint Spine Meeting. Laboratory investigation. J Neurosurg Spine. 2010;13(6):688-94.

3. Tofuku K, Koga H, Komiya S. Cervical pedicle screw insertion using a gutter entry point at the transitional area between the lateral mass and lamina. Eur Spine J. 2012;21(2):353-8.

4. KotaniY, Cunningham BW, Abumi K, McAfee PC. Biomechanical analysis of cervical stabilization systems. An assessment of transpedicular screw fixation in the cervical spine. Spine (Phila Pa 1976). 1994:19(22):2529-39.

5. Jones EL, Heller JG, Silcox DH, Hutton WC. Cervical pedicle screws versus lateral mass screws. Anatomic feasibility and biomechanical comparison. Spine (Phila Pa 1976). 1997;22(9):977-82

6. Karaikovic EE, Daubs MD, Madsen RW, Gaines RW Jr. Morphologic characteristics of human cervical pedicles. Spine (Phila Pa 1976). 1997;22(5):493-500.

7. Ludwig SC, Kramer DL, Vaccaro AR, Albert TJ. Transpedicle screw fixation of the cervica spine. Clin Orthop Relat Res. 1999;(359):77-88.

8. Panjabi MM, Shin EK, Chen NC, Wang JL. Internal morphology of human cervical pedicles. Spine (Phila Pa 1976). 2000;25(10):1197-205.

9. Zheng X, Chaudhari R, Wu C, Mehbod AA, Transfeldt EE. Subaxial cervical pedicle screw insertion with newly defined entry point and trajectory: accuracy evaluation in cadavers. Eur Spine J. 2010;19(1):105-12.

10. Karaikovic EE, Yingsakmongkol W, Gaines RW Jr. Accuracy of cervical pedicle screw placement using the funnel technique. Spine (Phila Pa 1976). 2001;26(22):2456-62.

11. Ludwig SC, Kramer DL, Balderston RA, Vaccaro AR, Foley KF, Albert TJ. Placement of pedicle screws in the human cadaveric cervical spine: comparative accuracy of three techpedicle screws in the human cadaveric cervical spin
niques. Spine (Phila Pa 1976). 2000:25(13):1655-67.

12. Miller RM, Ebraheim NA, Xu R, Yeasting RA. Anatomic consideration of transpedicular screw placement in the cervical spine. An analysis of two approaches. Spine (Phila Pa 1976). 1996;21(20):2317-22.
13. Reinhold M, Magerl F, Rieger M, Blauth M. Cervical pedicle screw placement: feasibility and accuracy of two new insertion techniques based on morphometric data. Eur Spine $\mathrm{J}$. 2007:16(1):47-56.

14. Richter M, Cakir B, Schmidt R. Cervical pedicle screws: conventional versus computer assisted placement of cannulated screws. Spine (Phila Pa 1976). 2005;30(20):2280-7.

15. Abumi K, Shono Y, Ito M, Taneichi H, Kotani Y, Kaneda K. Complications of pedicle screw fixation in reconstructive surgery of the cervical spine. Spine (Phila Pa 1976). 2000;25(8):962-9.

16. Hasegawa K Hirano T, Shimoda $\mathrm{H}$, Homma T, Morita O Indications for cervical pedicle screw instrumentation in nontraumatic lesions. Spine (Phila Pa 1976). 2008;33(21):2284-9.

17. Richter M, Mattes T, Cakir B. Computer-assisted posterior instrumentation of the cervical and cervico-thoracic spine. Eur Spine J. 2004;13(1):50-9.

18. Lee DH, Lee SW, Kang SJ, Hwang CJ, Kim NH, Bae JY, et al. Optimal entry points and trajectories for cervical pedicle screw placement into subaxial cervical vertebrae. Eur Spine J. 2011;20(6):905-11.

19. Lee SH, Kim KT, Abumi K, Suk KS, Lee JH, Park KJ. Cervical pedicle screw placement using the "key slot technique": the feasibility and learning curve. J Spinal Disord Tech. 2012;25(8):415-21.

20. Kotani Y, Abumi K, Ito M, Minami A. Improved accuracy of computer-assisted cervical pedicle screw insertion. J Neurosurg. 2003;99(Suppl 3):257-63.

21. Ishikawa Y, Kanemura T, Yoshida G, Ito Z, Muramoto A, Ohno S. Clinical accuracy of three-dimensional fluoroscopy-based computer-assisted cervical pedicle screw placement: a retrospective comparative study of conventional versus computer-assisted cervical pedicle screw placement. J Neurosurg Spine. 2010;13(5):606-11

22. Ito $Y$, Sugimoto $Y$, Tomioka M, Hasegawa $Y$, Nakago $K$, Yagata $Y$. Clinical accuracy of 3D fluoroscopy-assisted cervical pedicle screw insertion. J Neurosurg Spine. 2008:9(5):450-3

23. Yukawa Y, Kato F, Ito K, Horie Y, Hida T, Nakashima H, Machino M. Placement and complications of cervical pedicle screws in 144 cervical trauma patients using pedicle axis view techniques by fluoroscope. Eur Spine J. 2009;18(9):1293-9.

24. Desai S, Sethi A, Ninh CC, Bartol S, Vaidya R. Pedicle screw fixation of the C7 vertebra using an anteroposterior fluoroscopic imaging technique. Eur Spine J. 2010;19(11):1953-9. 